\title{
Antioxidative degradation product from purpurogallin induced by gamma irradiation
}

\author{
Gyeong Han Jeong, Tae Hoon Kim* \\ Department of Food Science and Biotechnology, Daegu University, Gyeongsan 38453, Korea
}

\section{Purpurogallin의 감마선 조사에 따라 생성되는 항산화 물질}

\author{
정경한 · 김태훈* \\ 대구대학교 식품공학과
}

\begin{abstract}
Gamma irradiation is a promising technique for improving the quality, safety, and shelf-life of foods. However, research on radiation-induced systemic degradation related to changes in the chemical structure and biological activity is still limited. In this study, radiolytic degradation and antioxidant activity enhancement of purpurogallin were studied in response to varying dose of gamma irradiation. Pure purpurogallin in methanol was exposed to gamma rays from 10 to 100 kGy. Purpurogallin reaction mixture was completely degraded when irradiated with 50 kGy and showed an increased antioxidation activity against 2,2-diphenyl-1-picrylhydrazyl (DPPH) and 2,2'-azino-bis (3-ethylbenzothiazoline-6-sulfonic acid) $\left(\mathrm{ABTS}^{\dagger}\right)$. It also exhibited hydroxyl radical scavenging ability. The structure of the newly-formed simple phenolic compound, pyrogallol (2) from gamma irradiated purpurogallin at $50 \mathrm{kGy}$ was characterized using ${ }^{1} \mathrm{H},{ }^{13} \mathrm{C}$, heteronuclear singles quantum coherence (HSQC), and heteronuclear multiple bond correlation (HMBC) NMR, and fast atom bombardment mass (FABMS) spectroscopy. Compared to the parent purpurogallin, the small phenolic molecule (2) exhibited significantly enhanced antioxidant activity against $\mathrm{DPPH}, \mathrm{ABTS}^{+}$, and hydroxyl radical scavenging activities with $\mathrm{SC}_{50}$ values of $9.5 \pm 0.3,12.6 \pm 0.4$, and $48.1 \pm 0.9 \mu \mathrm{M}$, respectively. These results indicate that degradation of purpurogallin induced by gamma irradiation might enhance its antioxidant property.
\end{abstract}

Key words : gamma irradiation, purpurogallin, DPPH, $\mathrm{ABTS}^{+}$, hydroxyl radical

*Corresponding author. E-mail : skyey7@daegu.ac.kr, Phone : +82-53-850-6533, Fax : +82-53-850-6539

Received 10 May 2021; Revised 21 June 2021; Accepted 28 June 2021.

Copyright (c) The Korean Society of Food Preservation.

This is an Open Access article distributed under the terms of the Creative Commons Attribution Non-Commercial License (http://creativecommons.org/licenses/by-nc/4.0) which permits unrestricted non-commercial use, distribution, and reproduction in any medium, provided the original work is properly cited. catalase, peroxidase 등의 항산화 효소 및 비타민 C, 비타민 $\mathrm{D}$ 및 glutathione 등과 같은 항산화 물질이 존재한다(Fang 등, 2002). 하지만 과도하게 생성된 산화적 스트레스는 세포 의 구성성분인 지질, 당, 단백질 및 $\mathrm{DNA}$ 를 비선택적, 비가역 적 파괴를 촉진시켜 노화, 암, 뇌질환, 심혈관계질환 및 피부 질환 등의 각종 성인병을 유발한다(Lobo 등, 2010). 따라서 체내의 활성산소종 및 자유라디칼을 억제하고 조절하여 노 화방지 및 성인병 예방 등의 기능을 하는 추가적인 성분이 필요하다(Hussain 등, 2003). 최근 butylated hydroxyanisol, 
butylated hydroxytoluene 및 tertiary butylhydroquinone 등과 같은 합성 항산화제가 개발되었으나, 이들 합성 항산화제들 은 독성 및 발암성 등의 부작용이 발견되어 사용을 제한하고 있어(Williams 등, 1999) 보다 안정하고 부작용이 적은 천연 항산화제의 개발이 필요한 실정이다(Lee 등, 1998).

Purpurogallin은 benzotropolone 골격의 화합물로 Quercus 속의 오배자(nutgall)에 주요 성분으로 알려져 있으며(AbouKaram과 Thomas, 1999), pyrogallol의 산화반응에 의해 생성 되는 것으로 보고되어 있다(Critchlow 등, 1967). 이전 연구 에서 purpurogallin은 tyrosine-specific protein kinase(AbouKaram과 Thomas, 1999), xanthine oxidase(Honda 등, 2017) 및 glutathione $S$-transferase(Das 등, 1984) 등의 효소 저해활 성이 보고가 되었으며, 항염증(Park 등, 2013), 항혈소판(Ku 와 $\mathrm{Bae}, 2014)$, 항골다공증(Kim 등, 2018) 및 항균(Inamori 등, 1997) 등 다양한 기능성 활성을 나타내는 화합물로 알려 져 있다. 최근 연구에서는 식도암(esophageal cancer) 관련 세 포 및 동물실험에 우수한 항암 활성이 보고가 되었다(Xie 등, 2019).

감마선 조사는 식품에 직접적인 가열처리를 하지 않고 살 균, 멸균 및 저장기간의 연장 등의 식품 품질을 향상시키는 기술로 세계적으로 많이 사용되고 있다(Farkas, 1998). 이전 부터 감마선 조사 기술은 식품의 물리 화학적 특성 변화와 관련된 연구가 활발히 진행 중이며(Nagy 등, 2011; Song 등, 2007), 그중 녹차(green tea) 추출물에 감마선을 조사한 결과, 항산화와 관련된 활성이 상승한 것이 보고가 되었다(Lee 등, 2006). 또한 감마선 조사된 잔디(Eremochloa ophiuroides) 추 출물에서 미백 및 주름개선과 관련된 tyrosinase 및 elastase 효 소를 효과적으로 저해하는 것이 보고가 되었고(Lee 등, 2013), anthocyanin 화합물인 cyanidin-3-O-xylosylrutinoside가 함유 되어 있는 오미자(Schizandra chinensis) 추출물에 감마선을 조사한 결과, cyanidin-3-O-xylosylrutinoside의 함량이 감소 되고, 신규 생성된 물질이 LC-MS 분석으로 구조 동정되었으 며, 색소 제거 메커니즘이 검증되었다(Lee 등, 2011). 또한 flavonoid, phenylpropanoid, chlacone 및 xanthone 등의 다양 한 페놀성 화합물에 감마선 조사시 구조 변환된 신규 물질이 동정되었으며, 우수한 기능성 활성 등이 보고가 되었다(Byun 등, 2018; Jo 등, 2016). 하지만 benzotropolone 골격의 화합 물에 대한 감마선 조사에 의한 구조 변환 및 기능성 상승과 관련된 연구 결과는 없었다.

본 연구에서는 대표적인 benzotropolone 골격의 화합물인 purpurogallin에 감마선 조사 후 신규 생성된 화합물을 HPLC 분석으로 확인하였으며, 각 선량별 purpurogallin 조사산물을 항산화 활성과 관련된 $\mathrm{DPPH}, \mathrm{ABTS}^{+}$및 hydroxyl 라디칼 소 거활성 평가를 수행하였다. 신규 생성물을 칼럼크로마토그래
피 및 기기분석을 이용하여 구조를 동정하였으며, 분리된 화 합물에서 강한 라디칼 소거활성을 확인하였기에 그 결과를 보고하고자 한다.

\section{재료 및 방법}

\section{시약 및 기기}

본 실험에서 사용한 purpurogallin과 라디칼 소거활성 평가 에 사용된 1,1-diphenyl-2-picrylhydrazyl(DPPH), 2,2'-azino-bis (3-ethylbenzothiazoline-6-sulfonic acid)( $\mathrm{ABTS}^{+}$), deoxyribose 및 (+)-catechin 등의 시약은 Sigma Chemical Co.(St Louis, $\mathrm{MO}, \mathrm{USA})$ 에서 구입하여 사용하였다. ${ }^{1} \mathrm{H}$ 및 ${ }^{13} \mathrm{C} \mathrm{NMR}$ 스펙 트럼은 $\mathrm{CD}_{3} \mathrm{OD}$ 용매 $\left(\delta_{\mathrm{H}} 3.35, \delta_{\mathrm{C}} 49.0\right)$ 를 이용하여 $600 \mathrm{MHz}$ FT-NMR spectrometer(FT-NMR, Varian VNS600, Palo alto, CA, USA)로 측정하였으며, 분석 및 column chromatography 용 용매는 특급시약을 사용하였다. FABMS 스펙트럼은 JMS700 spectrometer(JEOL, Tokyo, Japan)를 활용하여 분자량을 측정하였다.

\section{감마선 조사 및 $\mathrm{HPLC}$ 분석}

순수한 purpurogallin(200 mg)을 methyl alcohol(MeOH) $400 \mathrm{~mL}$ 에 녹인 후 바이알에 넣어 각 $10,25,50$ 및 $100 \mathrm{kGy}$ 선량으로 한국원자력연구원 첨단방사선연구소 내 선원 10 만 $\mathrm{Ci}$ 의 cobalt-60 감마선 조사시설(point source $\mathrm{AECL}$, IR-79, MDS Nordion international Co. Ltd., Ottawa, ON, Canada)을 이용하여 감마선 조사를 하였다(Jeong 등, 2018). 흡수선량 확인은 alanine dosimeter(5 mm, Bruker Instruments, Rheinstetten, Germany)를 사용하였으며, dosimeter는 국제원 자력기구(IAEA)의 규격에 준용하여 표준화한 후 사용하였 다. 각 선량별 조사된 purpurogallin 조사산물의 분석에는 HPLC(LC-20A, Shimadzu, Tokyo, Japan)와 ODS column (YMC gel ODS A-323, $4.6 \mathrm{~mm} \times 150 \mathrm{~mm}$ )을 사용하였다. 이 동상 용매로는 $0.1 \%$ formic acid(solvent $\mathrm{A}$ )와 acetonitrile (solvent $\mathrm{B}$ )을 사용하여 gradient elution을 $90 \% \mathrm{~A} ; 10 \% \mathrm{~B}$ 로 분석하여 $5 \mathrm{~min}, 5 \% \mathrm{~A} ; 95 \% \mathrm{~B}, 20 \mathrm{~min}$ 의 용매조성으로 물 질을 분석하였고, 이동상의 유속은 $1.0 \mathrm{~mL} / \mathrm{min}$ 으로 유지하 였으며, 검출기는 SPD-M20A(Shimadzu, Tokyo, Japan)를 이 용하여 $280 \mathrm{~nm}$ 에서 화합물을 검출하였다(Fig. 1).

\section{생성물질의 분리}

순수한 purpurogallin에 각 $10,25,50$ 및 $100 \mathrm{kGy}$ 선량으 로 감마선 조사한 후 각 조사산물을 항산화 활성과 관련된 $\mathrm{DPPH}, \mathrm{ABTS}^{+}$및 hydroxyl 라디칼 소거활성 평가를 수행하 였다. 그 결과, $50 \mathrm{kGy}$ 선량으로 조사된 purpurogallin 조사 


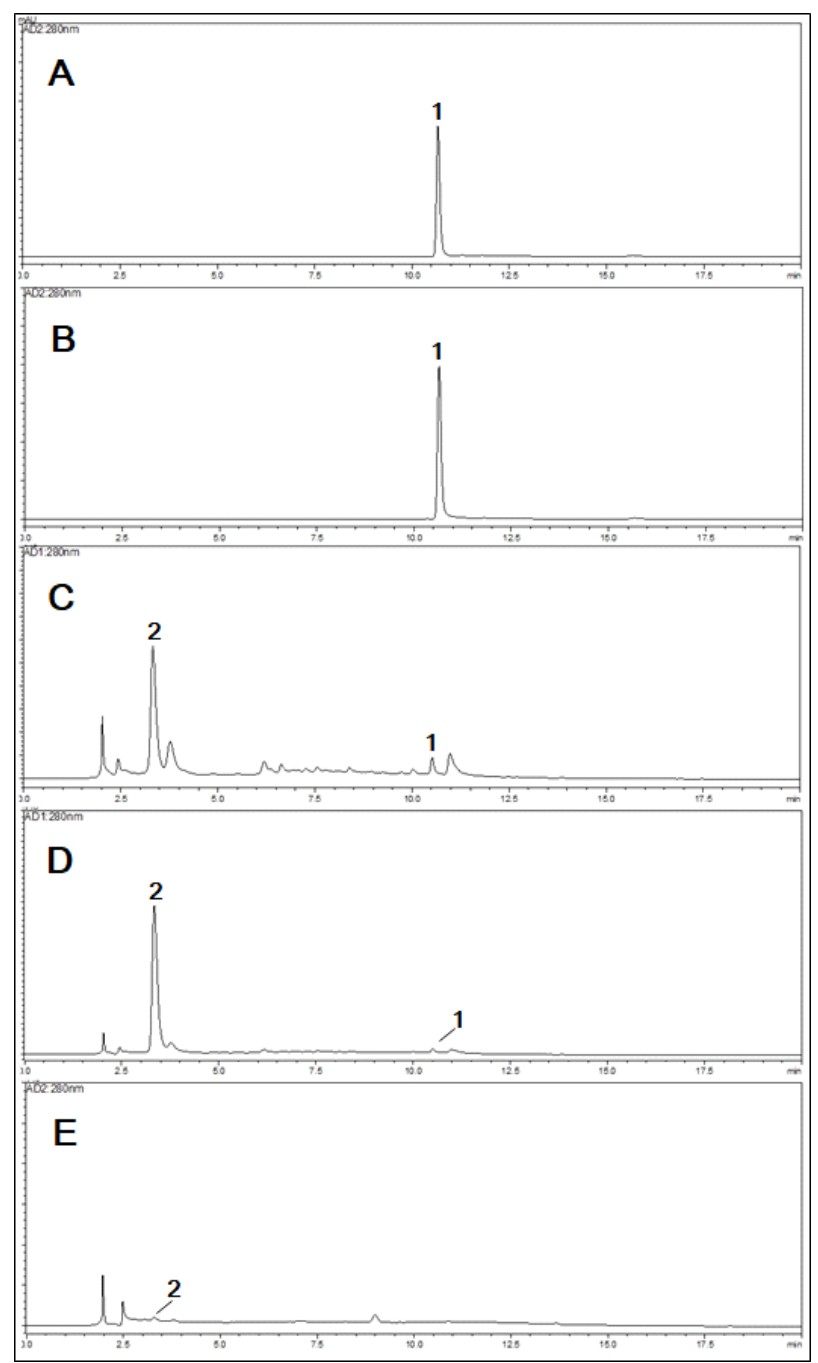

Fig. 1. HPLC chromatograms of gamma-irraidated purpurogallin at four different doses.

A, 0 (control); B, $10 \mathrm{kGy}$; C, $25 \mathrm{kGy}$; D, $50 \mathrm{kGy}$; E, $100 \mathrm{kGy}$.

1, purpurogallin; 2, pyrogallol.
산물에서 상대적으로 가장 우수한 라디칼 소거 활성을 나타 내어 활성물질의 분리 및 정제를 하였다(Table 1). $50 \mathrm{kGy}$ 선량으로 조사된 purpurogallin 조사산물 $(176 \mathrm{mg})$ 을 ODS gel(YMC gel ODS AQ 120-50S, YMC Co., Kyoto, Japan) 칼럼크로마토그래피 $(1 \mathrm{~cm}$ i.d. $\times 42 \mathrm{~cm})$ 및 semi-preparative $\mathrm{HPLC}$ 를 이용하여 화합물의 분리 및 정제를 수행하였으며, $10 \% \mathrm{MeOH}$ 을 용출하여 얻어진 fraction에서 화합물 2가 검출 되었고, 건조한 결과 $67.2 \mathrm{mg}$ 을 수득하였다. 분리된 단일물질 은 감마선 조사된 purpurogallin 분해산물과 비교·분석하여 pyrogallol $(2)\left(t_{\mathrm{R}} 3.3 \mathrm{~min}\right)$ 의 존재를 $\mathrm{HPLC}$ 분석으로 확인하였 고, NMR 및 FABMS 등의 기기분석을 활용하여 구조를 동정 하였다(Fig. 2).

\section{라디칼 소거활성 측정}

감마선 조사된 purpurogallin 조사산물 및 분리된 단일물 질의 DPPH 라디칼 소거활성은 Blois(1958)가 행한 방법을 변형하여 측정하였다. 각 시료용액 $120 \mu \mathrm{L}$ 에 $0.45 \mathrm{mM}$ 의 $\mathrm{DPPH}$ 용액 $60 \mu \mathrm{L}$ 를 넣고 교반한 후 15 분간 방치한 다음 ELISA reader(Infinite F200, Tecan Austria GmBH, Grödig, Austria)를 이용하여 $517 \mathrm{~nm}$ 에서 흡광도를 측정하였다.

$\mathrm{ABTS}^{+}$라디칼 소거능은 $\mathrm{Re}$ 등(1999)의 방법을 변형하여 다음과 같이 측정하였다. $7 \mathrm{mM} \mathrm{ABTS}{ }^{+}$와 $2.4 \mathrm{mM}$ 과황산칼 륨 동량을 혼합 후 암실에서 12 시간 방치하여 라디칼의 생성 을 유도하였다. 생성된 $\mathrm{ABTS}^{+}$라디칼 용액을 희석하여 734 $\mathrm{nm}$ 에서 흡광도 값이 0.7-0.8 정도가 되도록 희석한 후 사용 하였다. 희석한 $\mathrm{ABTS}^{+}$라디칼 용액 $100 \mu \mathrm{L}$ 와 각 선량별 조 사산물과 단일물질 $100 \mu \mathrm{L}$ 를 혼합하여 실온에서 7분간 반응 시킨 후 ELISA reader로 $734 \mathrm{~nm}$ 에서 흡광도를 측정하였다.

Hydroxyl 라디칼 소거활성은 deoxyribose 방법( $\mathrm{Li}, 2013)$ 을 변형하여 다음과 같이 측정하였다. $2.5 \mathrm{mM}$ deoxyribose, $1.5 \mathrm{mM} \mathrm{H}_{2} \mathrm{O}_{2}, 100 \mu \mathrm{M} \mathrm{FeCl}_{3}$ 및 $100 \mu \mathrm{M} \mathrm{EDTA}$ 를 $10 \mathrm{mM}$

Table 1. Comparison of radical scavenging activities of purpurogallin by gamma-irradiation dose

\begin{tabular}{|c|c|c|c|}
\hline \multirow{2}{*}{ Irradiation dose (kGy) } & \multicolumn{3}{|c|}{$\mathrm{SC}_{50}$ values $(\mu \mathrm{g} / \mathrm{mL})$} \\
\hline & DPPH & $\mathrm{ABTS}^{+}$ & Hydroxyl \\
\hline 0 (control) & $17.7 \pm 0.3^{\mathrm{al})}$ & $12.4 \pm 0.4^{\mathrm{a}}$ & $35.1 \pm 0.4^{\mathrm{a}}$ \\
\hline 10 & $15.5 \pm 0.4^{\mathrm{a}}$ & $10.7 \pm 0.2^{\mathrm{a}}$ & $30.9 \pm 0.3^{\mathrm{a}}$ \\
\hline 25 & $12.8 \pm 0.5^{\mathrm{b}}$ & $4.8 \pm 0.3^{b}$ & $25.1 \pm 0.2^{c}$ \\
\hline 50 & $10.8 \pm 0.1^{\mathrm{c}}$ & $3.5 \pm 0.1^{\mathrm{c}}$ & $24.5 \pm 0.6^{\mathrm{c}}$ \\
\hline 100 & $12.7 \pm 0.3^{\mathrm{b}}$ & $6.6 \pm 0.2^{\mathrm{b}}$ & $27.3 \pm 0.5^{\mathrm{b}}$ \\
\hline
\end{tabular}

${ }^{1)}$ Scavenging activities are expressed as the mean \pm SD of triplicate experiments. Different letters $\left({ }^{\mathrm{a}-\mathrm{c}}\right)$ within the same column indicate significant differences $(p<0.05)$. 


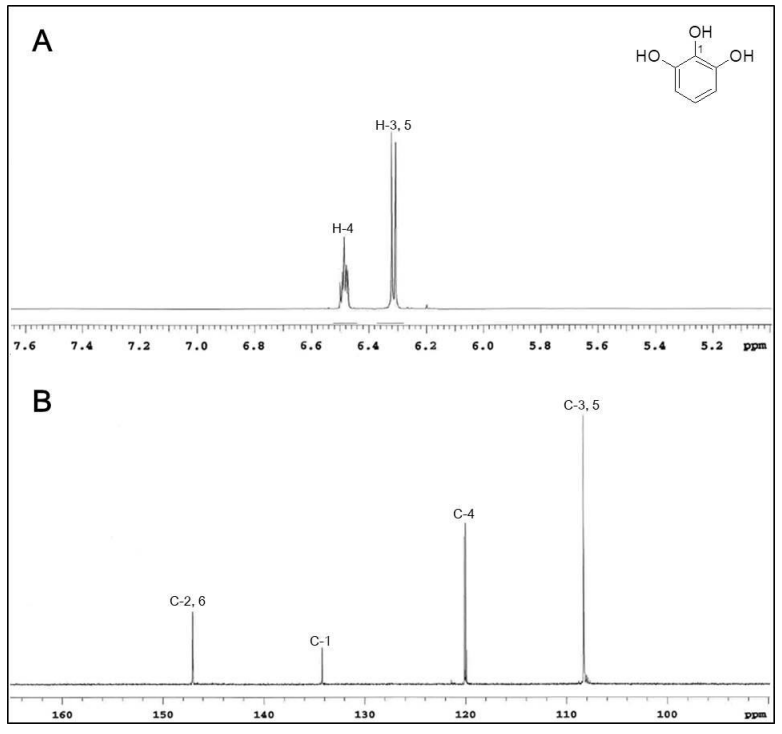

Fig. 2. ${ }^{1} \mathrm{H}$ (A) and ${ }^{13} \mathrm{C}$ (B) NMR spectra of newly-generated products 2.

Pyrogallol (2): White amorphous powder; FABMS $\mathrm{m} / \mathrm{z} 127[\mathrm{M}+\mathrm{H}]^{+}$; ${ }^{1} \mathrm{H}$ NMR $\left(\mathrm{CD}_{3} \mathrm{OD}, 600 \mathrm{MHz}\right): \delta_{\mathrm{H}} 6.48(1 \mathrm{H}, \mathrm{t}, J=8.4 \mathrm{~Hz}, \mathrm{H}-4), 6.32$ $(2 \mathrm{H}, \mathrm{d}, J=8.4 \mathrm{~Hz}, \mathrm{H}-3$ 과 $\mathrm{H}-5) ;{ }^{13} \mathrm{C} \mathrm{NMR}\left(\mathrm{CD}_{3} \mathrm{OD}, 150 \mathrm{MHz}\right): \delta_{\mathrm{C}}$ 147.0 (C-2와 C-6), 134.2 (C-1), 119.9 (C-4), 108.3 (C-3과 C-5).

phosphate buffer(pH 7.4)에 녹인 후 농도 별로 제조한 시료 에 첨가한다. 반응 시작 전 $100 \mu \mathrm{M}$ ascorbic acid를 첨가한 후 $37^{\circ} \mathrm{C}$ 에서 1 시간 동안 반응시킨다. 반응 후 $0.5 \%$ thiobarbituric acid와 $2.8 \%$ trichloroacetic acid를 첨가한 후 $80^{\circ} \mathrm{C}$ 의 온도에 서 20 분 동안 가열한다. 이후 급속 냉각시킨 후 ELISA reader 를 이용하여 $532 \mathrm{~nm}$ 에서 흡광도를 측정한다.

$\mathrm{DPPH}, \mathrm{ABTS}^{+}$및 hybroxyl 라디칼 소거활성 평가에 사용 한 양성대조군은 천연 항산화제로 알려진 (+)-catechin를 사 용하였으며, purpurogallin의 감마선 조사산물과 분리된 화합 물의 라디칼 소거활성은 시료용액의 첨가군과 무첨가군의 흡 광도 감소율을 확인하였고, $\mathrm{SC}_{50}$ (half maximal scavenging activity concentration)값은 시료가 $\mathrm{DPPH}, \mathrm{ABTS}^{+}$및 hybroxyl 라디칼을 $50 \%$ 소거하는 농도로 나타내었다.

\section{통계처리}

실험결과는 SPSS package program(version 20.0, SPSS Inc., Chicago, IL, USA)을 이용하여 각 실험군 간의 유의성 을 검증한 후 Ducan's multiple range test에 의해 실험군 간 의 차이를 $\mathrm{p}<0.05$ 유의수준에서 검증하였다.

\section{결과 및 고찰}

\section{Purpurogallin에 감마선 조사 후 생성된 화합물의 분리} 순수한 purpurogallin을 $\mathrm{MeOH}$ 에 녹인 후 $10,25,50$ 및
$100 \mathrm{kGy}$ 선량으로 감마선을 조사 후 농축하였으며, 감마선 조사 선량별 purpurogallin 조사산물에 대해 항산화 활성과 관련된 $\mathrm{DPPH}, \mathrm{ABTS}^{+}$및 hydroxyl 라디칼 소거활성 평가를 수행하였다. DPPH 라디칼 소거 활성 평가에서 10 및 $25 \mathrm{kGy}$ 선량으로 조사된 purpurogallin 조사산물의 $\mathrm{SC}_{50}$ 값이 각 $15.5 \pm 0.4$ 및 $12.8 \pm 0.5 \mu \mathrm{g} / \mathrm{mL}$ 의 활성으로 대조군 $\left(\mathrm{SC}_{50}: 17.7 \pm\right.$ $0.3 \mu \mathrm{g} / \mathrm{mL}$ )에 비해 조금 상승한 라디칼 소거활성을 나타내었 으며, $50 \mathrm{kGy}$ 선량으로 조사된 조사산물의 $\mathrm{SC}_{50}$ 값이 $10.8 \pm$ $0.1 \mu \mathrm{g} / \mathrm{mL}$ 로 상대적으로 가장 우수한 DPPH 라디칼 소거활성 을 나타내었다. 하지만 $100 \mathrm{kGy}$ 선량으로 조사된 purpurogallin 조사산물의 $\mathrm{SC}_{50}$ 값은 $12.7 \pm 0.3 \mu \mathrm{g} / \mathrm{mL}$ 로 $50 \mathrm{kGy}$ 선량으로 조사된 조사산물에 비해 낮은 활성을 나타내었다.

$\mathrm{ABTS}^{+}$라디칼 소거활성 평가에서 25 및 $50 \mathrm{kGy}$ 선량으 로 조사된 purpurogallin 조사산물의 $\mathrm{SC}_{50}$ 값이 각 $4.8 \pm 0.3$ 및 $3.5 \pm 0.2 \mu \mathrm{g} / \mathrm{mL}$ 로 상승된 $\mathrm{ABTS}^{+}$라디칼 소거활성을 나타내 었고 hydroxyl 라디칼 소거활성에서도 역시 조사선량이 증가 함에 따라 라디칼 소거활성이 증가하는 경향을 나타내었으 며, $50 \mathrm{kGy}$ 선량으로 조사된 purpurogallin 조사산물의 $\mathrm{SC}_{50}$ 값이 $24.5 \pm 0.6 \mu \mathrm{g} / \mathrm{mL}$ 로 가장 우수한 라디칼 소거활성을 나 타내었다. 하지만 $100 \mathrm{kGy}$ 선량으로 조사된 purpurogallin 조사산물은 다소 낮은 라디칼 소거활성을 나타내었다(Table 1). 이에 각 선량별 조사산물을 HPLC를 이용하여 분석을 수 행한 결과, 25 및 $50 \mathrm{kGy}$ 선량으로 조사된 반응물에서 purpurogallin은 감소하였고, 신규 생성된 peak가 retention time $\left(t_{\mathrm{R}}\right) 3.3$ 분에서 검출되었다(Fig. 1). $100 \mathrm{kGy}$ 조사산물에 서도 신규 생성물이 미량 검출되었으며, 25 및 $50 \mathrm{kGy}$ 조사 산물보다 낮은 라디칼 소거활성은 신규 생성물의 함량에 의 한 차이임을 확인하였다. 가장 우수한 활성을 나타낸 $50 \mathrm{kGy}$ 선량으로 조사된 purpurogallin 조사산물의 신규 생성 물질은 ODS gel을 충진제로 활용한 칼럼크로마토그래피를 이용하 여 저분자 페놀 유도체를 분리하였다. 분리된 화합물은 구조 결정을 위하여 ${ }^{1} \mathrm{H},{ }^{13} \mathrm{C} \mathrm{NMR}$ 및 $\mathrm{FABMS}$ 스펙트럼을 측정하 였다(Fig. 2).

화합물 2는 흰색의 무결정형 분말상으로 얻어졌으며, $\mathrm{FABMS}$ 측정 결과 $m / z 127[\mathrm{M}+\mathrm{H}]^{+}$에서 base peak를 확인하 여 $\mathrm{C}_{6} \mathrm{H}_{6} \mathrm{O}_{3}$ 의 분자식을 추정하였다. ${ }^{1} \mathrm{H} \mathrm{NMR}$ 스펙트럼 해석 으로 2 개의 방향족 proton 시그널을 $\delta_{\mathrm{H}} 6.48(1 \mathrm{H}, \mathrm{t}, J=8.4$ $\mathrm{Hz}, \mathrm{H}-4)$ 및 $6.32(2 \mathrm{H}, \mathrm{d}, J=8.4 \mathrm{~Hz}, \mathrm{H}-3$ 과 $\mathrm{H}-5)$ 로 관찰하였 다. 또한 ${ }^{13} \mathrm{C} \mathrm{NMR}$ 스펙트럼 해석으로 $\delta_{\mathrm{C}} 147.0(\mathrm{C}-2$ 와 C-6), 134.2(C-1), 119.9(C-4) 및 108.3(C-3과 C-5)에서 6개의 벤젠 유래의 carbon 시그널이 관찰되었다. 이상의 ${ }^{1} \mathrm{H}$ 및 ${ }^{13} \mathrm{C} \mathrm{NMR}$ 데이터 해석과 문헌치(Kularni 등, 2008) 및 표품과의 HPLC를 직접 비교하여 화합물 2는 저분자 페놀성 화합물인 pyrogallol 로 구조 동정하였다(Fig. 2). 


\section{신규 생성된 화합물의 라디칼 소거활성 평가}

감마선 조사된 purpurogallin 조사산물에서 우수한 라디칼 소거활성을 확인하였고, ODS gel을 충진제로 이용한 칼럼크 로마토그래피 및 기기분석을 이용하여 신규 생성된 화합물의 분리 및 정제를 수행하였다. 분리된 화합물은 저분자 페놀성 화합물인 pyrogallol(2)으로 구조 동정하였으며, 항산화 활성 과 관련된 $\mathrm{DPPH}, \mathrm{ABTS}^{+}$및 hydroxyl 라디칼 소거활성 평가 를 수행하였다. 그 결과, 신규 생성된 저분자 페놀성 화합물인 pyrogallol(2)의 $\mathrm{DPPH}$ 라디칼 소거능의 $\mathrm{SC}_{50}$ 값은 $9.5 \pm 0.3 \mu \mathrm{M}$ 로 나타내었으며, purpurogallin(1)( $\left.\mathrm{SC}_{50}: 65.1 \pm 1.0 \mu \mathrm{M}\right)$ 에 비 해 월등히 상승된 활성임을 확인하였다.

$\mathrm{ABTS}^{+}$라디칼 소거능에서 감마선 조사된 purpurogallin 조사산물에서 신규 생성된 화합물 2 의 $\mathrm{SC}_{50}$ 값이 $12.6 \pm 0.4$ $\mu \mathrm{M}$ 으로 우수한 $\mathrm{ABTS}^{+}$라디칼 소거활성을 나타내었으며, hydroxyl 라디칼 소거능에서도 $48.1 \pm 0.9 \mu \mathrm{M}$ 의 $\mathrm{SC}_{50}$ 값을 나 타내어 purpurogallin에 비해 상승된 라디칼 소거활성을 나타 내었다. 감마선 조사된 purpurogallin 조사산물로부터 신규 생성된 저분자 페놀성 화합물 $\mathbf{2}$ 는 항산화 활성 평가에서 양 성대조군으로 사용된 천연 항산화제인 (+)-catechin보다 우수 한 $\mathrm{DPPH}, \mathrm{ABTS}^{+}$및 hydroxyl 라디칼 소거 활성을 나타내었 다(Table 2).

최근 연구에서 콩과 식물의 주요 성분인 genistein에 감마 선을 조사한 결과, 신규 생성된 genistein 유도체가 genistein보 다 우수한 항산화 활성을 나타냄이 보고가 되었다(Jung 등, 2009). 또한 감마선 조사된 cyanidin 3-rutinoside 조사산물로부 터 신규 생성된 phenolic acid 유도체 화합물인 protocatechuic acid methyl ester가 구조 동정되었고, 우수한 DPPH 라디칼 소거활성이 보고가 되었다(Lee 등, 2014). 본 연구에서도 purpurogallin에 감마선 조사로 신규 생성된 저분자 페놀 유 도체를 분리 및 구조 동정하였고, 항산화 활성과 관련된 $\mathrm{DPPH}, \mathrm{ABTS}^{+}$및 hydroxyl 라디칼 소거활성 평가에서 우수 한 소거활성을 확인하였다. 향후 신규 생성물은 세포 실험 및 동물 실험을 통해 항산화 활성 기작에 대한 연구가 필요하며, 이상의 연구 결과는 감마선 조사시 생성되는 화합물의 구조
및 항산화 활성 변화와 관련된 기초자료로서의 활용이 가능 할 것으로 사료된다.

\section{요 약}

감마선 조사에 의해 생성된 물질에 대해 천연 항산화제 개 발을 위해 본 연구를 수행하였으며, purpurogallin(1)에 10, 25,50 및 $100 \mathrm{kGy}$ 선량으로 감마선을 조사하였고, 각 선량 별 조사산물에 대하여 항산화 활성과 관련된 $\mathrm{DPPH}, \mathrm{ABTS}^{+}$ 및 hydroxyl 라디칼 소거활성 평가를 수행하였다. 그 결과, $50 \mathrm{kGy}$ 선량으로 조사된 purpurogallin 조사산물에서 DPPH 라디칼 소거활성의 $\mathrm{SC}_{50}$ 값이 $10.8 \pm 0.1 \mu \mathrm{g} / \mathrm{mL}$ 로 다른 조사 선량에 비해 가장 우수한 라디칼 소거활성을 나타내었다. $\mathrm{ABTS}^{+}$및 hydroxyl 라디칼 소거활성 평가에서도 각 $3.5 \pm 0.1$ 및 $24.5 \pm 0.6 \mu \mathrm{g} / \mathrm{mL}$ 의 $\mathrm{SC}_{50}$ 값을 나타내어 $50 \mathrm{kGy}$ 조사산물 에 라디칼 소거활성을 나타내는 물질의 존재함을 시사하였 다. 이에 각 조사산물에 대해 HPLC 분석을 수행하였으며, 25 및 $50 \mathrm{kGy}$ 조사산물에서 purpurogallin 이외에 신규 생성된 화합물을 확인하였다. 가장 우수한 활성을 나타낸 $50 \mathrm{kGy}$ 조 사산물을 ODS gel을 충진제로 활용한 칼럼크로마토그래피 를 수행하여 저분자 phenol 유도체를 분리 및 정제하였고, 화 합물의 구조는 분광학적 기기 분석을 통하여 pyrogallol(2)로 구조 동정하였다. 분리된 화합물은 라디칼 소거활성 평가를 수행하였으며, $\mathrm{DPPH}$ 라디칼 소거능의 $\mathrm{SC}_{50}$ 값이 $9.5 \pm 0.3 \mu \mathrm{M}$ 로 매우 강한 라디칼 소거활성을 나타내었고, $\mathrm{ABTS}^{+}$라디칼 소거능에서도 역시 $\mathrm{SC}_{50}$ 값이 $12.6 \pm 0.4 \mu \mathrm{M}$ 로 purpurogallin $\left(\mathrm{SC}_{50}: 36.3 \pm 0.6 \mu \mathrm{M}\right)$ 보다 월등히 상등된 라디칼 소거활성을 나타내었다. 또한 hydroxyl 라디칼 소거활성 평가에서도 $48.1 \pm 0.9 \mu \mathrm{M}$ 의 $\mathrm{SC}_{50}$ 값을 나타내었으며, 양성대조군으로 사 용한 천연 항산화제인 $(+)$-catechin $\left(\mathrm{SC}_{50}: 60.9 \pm 1.4 \mu \mathrm{M}\right)$ 보다 우수한 라디칼 소거능을 나타내었다. 이상의 연구결과로부터 purpurogallin에 감마선 조사는 저분자 페놀성 화합물인 pyrogallol의 생성을 확인하였으며, 우수한 라디칼 소거활성 을 나타내었다. 향후 감마선 조사시 식품의 주요 성분들의 구

Table 2. Radical scavenging activities of newly-generated product from purpurogallin by gamma irradiation

\begin{tabular}{|c|c|c|c|}
\hline \multirow{2}{*}{ Compounds } & \multicolumn{3}{|c|}{$\mathrm{SC}_{50}$ values $(\mu \mathrm{M})$} \\
\hline & DPPH & $\mathrm{ABTS}^{+}$ & Hydroxyl \\
\hline Purpurgallin (1) & $65.1 \pm 1.0^{\mathrm{al})}$ & $36.3 \pm 0.6^{\mathrm{a}}$ & $124.9 \pm 1.7^{\mathrm{a}}$ \\
\hline Pyrogallol (2) & $9.5 \pm 0.3^{\mathrm{c}}$ & $12.6 \pm 0.4^{\mathrm{b}}$ & $48.1 \pm 0.9^{c}$ \\
\hline$(+)$-Catechin ${ }^{2)}$ & $22.4 \pm 0.7^{b}$ & $14.7 \pm 0.5^{\mathrm{b}}$ & $60.9 \pm 1.4^{\mathrm{b}}$ \\
\hline
\end{tabular}

${ }^{1)}$ Scavenging activities are expressed as the mean \pm SD of triplicate experiments. Different letters $\left({ }^{\mathrm{a}-\mathrm{c}}\right)$ within the same column indicate significant differences $(\mathrm{p}<0.05)$.

${ }^{2)}(+)$-Catechin was used as a positive control. 
조변환 양상과 활성 상승과 관련하여 다양한 조건에서 체계 적인 연구가 필요하다고 생각된다.

\section{Conflict of interests}

The authors declare no potential conflict of interest.

\section{ORCID}

Gyeong Han Jeong

https://orcid.org/0000-0001-7115-4945

Tae Hoon Kim https://orcid.org/0000-0003-0428-2829

\section{References}

Abou-Karam M, Thomas Shier W. Inhibition of oncogene product enzyme activity as an approach to cancer chemoprevention. Tyrosine-specific protein kinase inhibition by purpurogallin from Quercus sp. nutgall. Phytother Res, 13, 337-340 (1999)

Blois MS. Antioxidant determinations by the use of a stable free radical. Nature, 181, 1199-1200 (1958)

Byun EB, Kim HM, Sung NY, Yang MS, Kim WS, Choi D, Mushtaq S, Lee SS, Byun EH. Gamma irradiation of aloe-emodin induced structural modification and apoptosis through a ROS- and caspase-dependent mitochondrial pathway in stomach tumor cells. Int J Radiat Biol, 94, 403-416 (2018)

Critchlow A, Haslam E, Haworth RD, Tinker PB, Waldron NM. The oxidation of some pyrogallol and purpurogallin derivatives. Tetrahedron, 23, 2829-2847 (1967)

Das M, Bickers DR, Mukhtar H. Plant phenols as in vitro inhibitors of glutathione $S$-transferase(s). Biochem Bioph Res Co, 120, 427-433 (1984)

Fang YZ, Yang S, Wu G. Free radicals, antioxidants, and nutrition. Nutrition, 18, 872-879 (2002)

Halliwell B, Aruoma OI. DNA damage by oxygen-derived species. Its mechanism and measurement in mammalian systems. FEBS Lett, 281, 9-19 (1991)

Honda S, Fukuyama Y, Nishiwaki H, Masuda A, Masuda, T. Conversion to purpurogallin, a key step in the mechanism of the potent xanthine oxidase inhibitory activity of pyrogallol. Free Radical Bio Med, 106, 228-235 (2017) Hussain HH, Babic G, Durst T, Wright JS, Flueraru M,
Chichirau A, Chepelev LL. Development of novel antioxidants: Design, synthesis, and reactivity. J Org Chem, 68, 7023-7032 (2003)

Inamori $\mathrm{Y}$, Muro C, Sajima E, Katagiri M, Okamoto Y, Tanaka H, Sakagami Y, Tsujibo H. Biological activity of purpurogallin. Biosci Biotechnol Biochem, 61, 890892 (1997)

Jeong GH, Cho JH, Jo C, Lee S, Lee SS, Bai HW, Chung BY, Kim TH. Gamma irradiation-assisted degradation of rosmarinic acid and evaluation of structures and antiadipogenic properties. Food Chem, 258, 181-188 (2018)

Jo C, Yoon KY, Jang EJ, Kim TH. Degradation products of mangiferin by gamma irradiation with inhibitory effects on NO production. Biosci Biotechnol Biochem, 80, 2022-2024 (2016)

Jung HJ, Park HR, Jung U, Jo SK. Radiolysis study of genistein in methanolic solution. Radiat Phys Chem, 78, 386-393 (2009)

Kim K, Kim TH, Ihn HJ, Kim JE, Choi JY, Shin HI, Park EK. Inhibitory effect of purpurogallin on osteoclast differentiation in vitro through the downregulation of c-Fos and NFATc1. Int J Mol Sci, 19, 601-612 (2018)

$\mathrm{Ku}$ SK, Bae JS. Antiplatelet and antithrombotic activities of purpurogallin in vitro and in vivo. BMB Rep, 47, 376-381 (2014)

Kulkarni A, Suzuki S, Etoh H. Antioxidant compounds from Eucalyptus grandis biomass by subcritical liquid water extraction. J Wood Sci, 54, 153-157 (2008)

Lee EM, Lee SS, Bai HW, Cho JY, Kim TH, Chung BY. Effect of gamma irradiation on the pigments and the biological activities of methanolic extracts from leaves of centipedegrass (Eremochloa ophiuroides Munro). Radiat Phys Chem, 91, 108-113 (2013)

Lee NY, Jo C, Sohn SH, Kim JK, Byun MW. Effects of gamma irradiation on the biological activity of green tea byproduct extracts and a comparison with green tea leaf extracts. J Food Sci, 71, 269-274 (2006)

Lee SK, Mbwambo ZH, Chung H, Luyengi L, Gamez EJ, Mehta RG, Kinghorn AD. Pezzuto JM. Evaluation of the antioxidant potential of natural products. Chmb Chem High T Scr, 1, 35-46 (1998)

Lee SS, Kim TH, Lee EM, Lee MH, Lee HY, Chung BY. Degradation of cyanidin-3-rutinoside and formation of protocatechuic acid methyl ester in methanol solution by 
gamma irradiation. Food Chem, 156, 312-318 (2014)

Lee SS, Lee EM, An BC, Kim TH, Lee KS, Cho JY, Yoo

SH, Bae JS, Chung BY. Effects of irradiation on decolourisation and biological activity in Schizandra chinensis extracts. Food Chem, 125, 214-220 (2011)

Li X. Solvent effects and improvements in the deoxyribose degradation assay for hydroxyl radical-scavenging. Food Chem, 141, 2083-2088 (2013)

Farkas, J. Irradiation as a method for decontaminating food: A review. Int J Food Microbiol, 44, 189-204 (1998)

Lobo V, Patil A, Phatak A, Chandra N. Free radicals, antioxidants and functional foods: Impact on human health. Pharmacol Rev, 4, 118-126 (2010)

Nagy TO, Solar S, Sontag G, Koenig J. Identification of phenolic components in dried spices and influence of irradiation. Food Chem, 128, 530-534 (2011)

Park HY, Kim TH, Kim CG, Kim GY, Kim CM, Kim ND, Kim BW, Hwang HJ, Choi YH. Purpurogallin exerts anti-inflammatory effects in lipopolysaccharide-stimulated BV2 microglial cells through the inactivation of the NF$\kappa \mathrm{B}$ and MAPK signaling pathways. Int $\mathrm{J}$ Mol Med, 32, 1171-1178 (2013)

Re R, Pellegrini N, Proteggente A, Pannala A, Yang M, Rice-Evans, C. Antioxidant activity applying an improved ABTS radical cation decolorization assay. Free Radical Bio Med, 26, 1231-1237 (1999)

Song HP, Byun MW, Jo C, Lee CH, Kim KS, Kim DH. Effects of gamma irradiation on the microbiological, nutritional, and sensory properties of fresh vegetable juice. Food Control, 18, 5-10 (2007)

Xie X, Zu X, Liu F, Wang T, Wang X, Chen H, Liu K, Wang P, Liu F, Zheng Y, Bode AM, Dong Z, Kim DG. Purpurogallin is a novel mitogen-activated protein kinase kinase 1/2 inhibitor that suppresses esophageal squamous cell carcinoma growth in vitro and in vivo. Mol Carcinogens, 58, 1248-1259 (2019) 